Article

\title{
Synthesis and Evaluation of the Antioxidant Activity of Lipophilic Phenethyl Trifluoroacetate Esters by In Vitro ABTS, DPPH and in Cell-Culture DCF Assays
}

\author{
Roberta Bernini ${ }^{1, * \mathbb{D}}$, Maurizio Barontini ${ }^{1}$, Valentina Cis ${ }^{1}$, Isabella Carastro ${ }^{1}$, \\ Daniela Tofani ${ }^{2,3, *(D)}$, Rosa Anna Chiodo ${ }^{2}$, Paolo Lupattelli ${ }^{4}$ and Sandra Incerpi ${ }^{2}$ (D) \\ 1 Department of Agricultural and Forestry Sciences (DAFNE), University of Tuscia, Via S. Camillo de Lellis, \\ 01100 Viterbo, Italy; barontinimaurizio@gmail.com (M.B.); r_vale87@libero.it (V.C.); isabella109@alice.it (I.C.) \\ 2 Department of Sciences, University Roma Tre, Viale G. Marconi 446, 00146 Rome, Italy; \\ rosa.anna.chiodo@gmail.com (R.A.C.); sandra.incerpi@uniroma3.it (S.I.) \\ 3 Centro Interdipartimentale di Servizi per la Didattica della Chimica (CIDSiC), University Roma Tre, \\ Via della Vasca Navale 79, 00146 Rome, Italy \\ 4 Department of Sciences, University of Basilicata, Via dell'Ateneo Lucano 10, 85100 Potenza, Italy; \\ paolo.lupattelli@unibas.it \\ * Correspondence: berninir@unitus.it (R.B.); daniela.tofani@uniroma3.it (D.T.); \\ Tel.: +39-0761-357452 (R.B.); +39-06-57333371 (D.T.)
}

Received: 29 December 2017; Accepted: 16 January 2018; Published: 19 January 2018

\begin{abstract}
Polyphenols are natural compounds showing a variety of health-promoting effects. Unfortunately, due to low lipid solubility, their applications in the pharmaceutical, food, and cosmetic industries are limited. With the aim of obtaining novel lipophilic derivatives, the present study reports the synthesis of a series of phenethyl trifluoroacetate esters containing up to two hydroxyl groups in the aromatic ring. Experimental $\log \mathrm{P}$ values confirmed a greater lipophilicity of the novel compounds compared to the parent compounds. The radical scavenging capacity of all phenethyl trifluoroacetate esters was evaluated by in vitro assays (ABTS, DPPH) and in cultured cells (L6 myoblasts and THP-1 leukemic monocytes) using $2^{\prime}, 7^{\prime}$-dichlorodihydrofluorescein diacetate. These data revealed that the esters showed a good antioxidant effect that was strictly dependent on the grade of hydroxylation of the phenyl ring. The lack of toxicity, evaluated by the MTT assay and proliferation curves, makes these trifluoroacetates attractive derivatives for pharmaceutical, food, and cosmetic applications.
\end{abstract}

Keywords: phenethyl trifluoroacetate esters; tyrosol trifluoroacetate; hydroxytyrosol trifluoroacetate; lipophilic antioxidants; ABTS assay; DPPH assay; cell culture DCF assay

\section{Introduction}

In recent years, antioxidants have become of increasing interest for food, cosmetic, and pharmaceutical applications [1]. In this respect, polyphenols, a large family of compounds found in plants and plant-derived food and beverages, play an important role due to their well-recognized health-promoting effects [2,3]. In particular, they act as protective agents against oxidative attacks by blocking reactive oxygen species (ROS) and reactive nitrogen species (RNS) responsible for oxidative modifications of relevant biomolecules including polyunsaturated fatty acids and nucleic acids [4]. Such structural changes have important implications as they can lead to cell membrane modifications, DNA damage [5], and the development of serious diseases (cancer, diabetes, atherosclerosis, and neurodegenerative and cardiovascular disorders) [6].

Unfortunately, as phenolic compounds show poor lipid solubility, their applications in non-aqueous media (oils, fats, and emulsions) are limited, and their bioavailability in the cellular 
environment is generally low. These physicochemical properties can be conveniently modified by increasing the lipophilicity of polyphenols, namely introducing a hydrophobic moiety into the molecule without changing the phenolic or catecholic group responsible for the antioxidant activity. As an example, lipophilic polyphenols have been obtained by simple esterification [7-11] or etherification reactions [12] introducing long alkyl chains. As an alternative, in the literature, it is reported that the incorporation of fluorine atoms and trifluoromethyl groups into a molecule increases its lipophilicity and modulates the binding affinity in protein-ligand complexes, thus improving metabolic stability and exerting a relevant effect on the conformation of the molecule [13]. A significant number of drugs and bioactive compounds including phenols and flavonoids are halogenated structures [14-17]. For these reasons, in medicinal chemistry, fluorination represents a useful strategy to obtain lipophilic derivatives endowed of interesting physicochemical and pharmacodynamic properties [18,19].

Based on these literature data and our expertise on the synthesis of phenolic antioxidants [8-11,20,21], we obtained a series of novel trifluoroacetate esters from phenethyl alcohols containing up to two phenolic groups in the aromatic ring. Following evaluation of the lipophilicity of all compounds, we tested their antioxidant capacity by in vitro spectrophotometric analyses (ABTS, DPPH assays) and in cultured cells (L6 myoblasts from rat skeletal muscle and THP-1 human leukemic monocytes) after induction of oxidative stress by the radical generator cumene hydroperoxide using the intracellular fluorescent probe $2^{\prime}, 7^{\prime}$-dichlorodihydrofluorescein diacetate (DCF). Using the same cell lines, we also evaluated the capability of the novel compounds to modulate proliferation and cytotoxicity by the MTT assay. Finally, we estimated cell proliferation by cell counts.

\section{Results and Discussion}

\subsection{Synthesis of Phenethyl Trifluoroacetate Esters}

Biologically active compounds such as phenethyl alcohol 1, 2-hydroxyphenethyl alcohol 2, 3-hydroxyphenethyl alcohol 3, 4-hydroxyphenethyl alcohol (tyrosol) 4, 4-hydroxy-3-methoxyphenethyl alcohol (homovanillyl alcohol) 5, and 3,4-dihydroxyphenethyl alcohol (hydroxytyrosol) 6 were used as starting materials (Figure 1).<smiles>OCCc1ccccc1</smiles>

1<smiles>OCCc1ccccc1O</smiles>

2<smiles>OCCc1cccc(O)c1</smiles>

3<smiles>OCCc1ccc(O)cc1</smiles>

4<smiles>COc1cc(CCO)ccc1O</smiles>

5<smiles>OCCc1ccc(O)c(O)c1</smiles>

6

Figure 1. Phenethyl alcohols 1-6.

Phenethyl alcohol 1 is a flavoring molecule found in numerous foods and beverages, in particular beer and wine [22]. It is also an active ingredient of fragrance and antimicrobial preservatives in cosmetic formulations, including make-up and skin care products, shampoos, perfumes, and colognes. The safety of phenethyl alcohol has recently been assessed by the Cosmetic Ingredient Review (CIR) Expert Panel and the Food and Drug Administration (FDA) [23], which included it in the list of substances Generally Recognized As Safe (GRAS) [24]. In addition, it shows antimicrobial [25], antiviral [26] and antitumor effects [27]. The hydroxylated derivatives tyrosol 4, homovanillyl alcohol 5 , and hydroxytyrosol 6 are low-weight molecular phenols present in extra-virgin olive oil and olive oil by-products [28], well known for their beneficial health effects. Hydroxytyrosol 6 is the most relevant compound, characterized by a potent anticancer and antioxidant activity [29]. It has been widely studied in our laboratories and used for many applications ranging from the synthesis of 
novel bioactive compounds $[30,31]$ to its inclusion in PVA-based films for active food packaging applications [32,33].

In this study, we aimed to increase the lipophilicity of phenethyl alcohols 1-6 by derivatizing the alcoholic group with the introduction of a fluorinated moiety. The reactions were performed in the presence of trifluoroacetic acid used as both solvent and reagent at reflux temperature for $2 \mathrm{~h}$. The corresponding trifluoroacetate esters 7-12 were obtained in satisfactory to excellent yields and filtered on silica gel to afford pure samples. This synthetic route was original and, as previously observed by us in the carboxymethylation and acetylation reactions of tyrosol and hydroxytyrosol [34], only the alcoholic chain of substrates 1-6 was esterified (Scheme 1). However, extending the reaction time to $24 \mathrm{~h}$, trifluoroacetylation also occurred on the phenolic groups.

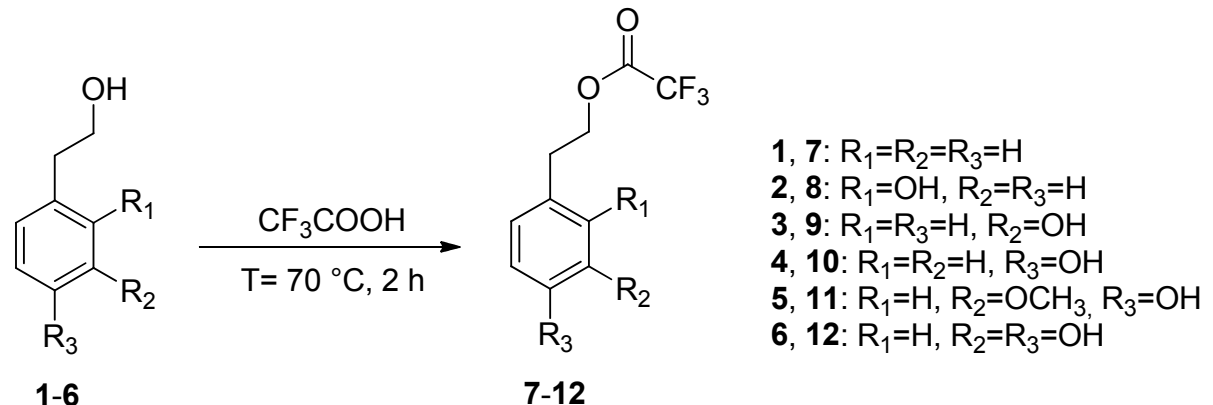

Scheme 1. Trifluoroacetylation reaction of phenethyl alcohols 1-6.

\section{2. $\log P$ Determination}

Lipophilicity is a relevant property to estimate the bioavailability and dispersion of a molecule in non-aqueous media (oils, fats, and emulsions) and in the cellular environment. Generally, it can be related to $\log \mathrm{P}$, a parameter that evaluates the partition of a molecule between two immiscible solvents (water and 1-octanol). The experimental $\log P$ values of all compounds were measured by UV-Vis spectrophotometry [35] and are reported in Table 1. As expected, among substrates 1-6, phenethyl alcohol 1 was characterized by the highest lipophilic character, hydroxytyrosol 6 by the lowest value followed by homovanillyl alcohol 5, while 2-hydroxyphenethyl alcohol 2, 3-hydroxyphenethyl alcohol 3, and tyrosol 4 showed similar values. As already reported in the literature [35], the lipophilic character increased from hydroxytyrosol 6 to homovanillyl alcohol 5 and tyrosol 4 .

Table 1. $\log P$ values of compounds 1-12.

\begin{tabular}{cc}
\hline Compound & LogP \pm SD $^{\mathbf{a}}$ \\
\hline $\mathbf{1}$ & $1.18 \pm 0.08$ \\
$\mathbf{2}$ & $0.72 \pm 0.07$ \\
$\mathbf{3}$ & $0.66 \pm 0.06$ \\
$\mathbf{4}$ & $0.69 \pm 0.05$ \\
$\mathbf{5}$ & $0.46 \pm 0.02$ \\
$\mathbf{6}$ & $0.10 \pm 0.01$ \\
$\mathbf{7}$ & $2.38 \pm 0.18$ \\
$\mathbf{8}$ & $2.05 \pm 0.16$ \\
$\mathbf{9}$ & $1.96 \pm 0.14$ \\
$\mathbf{1 0}$ & $1.98 \pm 0.14$ \\
$\mathbf{1 1}$ & $1.90 \pm 0.12$ \\
$\mathbf{1 2}$ & $1.62 \pm 0.12$ \\
\hline
\end{tabular}

${ }^{\mathrm{a}}$ Mean of triplicate determinations. 
A similar behavior was observed comparing the $\log \mathrm{P}$ values of trifluoroacetyl esters 7-12, which in all cases resulted in greater values than those of the parent compounds 1-6. In particular, esters 7 and $\mathbf{8}$ showed the highest $\log \mathrm{P}$ values, while compounds 9-11 showed comparable values. The increase of the $\log \mathrm{P}$ value of hydroxytyrosol trifluoroacetate 12 compared to hydroxytyrosol 6 was notable.

\subsection{ABTS and DPPH Spectrophotometric Assays}

Generally, the aim of in vitro radical scavenging experiments is to provide a preliminary appraisal of the antioxidant capacity of compounds and a premise of the structure/antioxidant activity relationship. As reported in Figure 2, the ABTS assay disclosed a very low antiradical activity of phenethyl alcohol 1 and its trifluoroacetate ester 7. Phenolic derivatives 2, 5, 6 and their corresponding esters 8, 11, 12 showed a good antioxidant capacity. Interestingly, in the phenolic derivatives 2-4, the aromatic ring position of the hydroxyl group appears to heavily influence the radical scavenging ability. Indeed, the ortho hydroxyl derivative 2 proved to be more antioxidant than the meta and para isomers 3 and 4. A similar behavior was observed regarding the trifluoroacetate ester derivative 8 , which showed a higher antioxidant activity than its isomers 9 and 10. This peculiar effect could be due to the formation of a hydrogen bond between the phenolic proton and the oxygen atom present in the alkyl chain, which may promote the generation of the radical species in accordance to already reported by us [9]. In the catecholic structures, the high hydrogen bond stabilization between the two phenol groups caused the alcohol hydrogen bond stabilization to be insignificant.

In the DPPH assay, $\mathrm{IC}_{50}$ values were measured and the anti-radical activities (ARA) were calculated (Table SI1). Comparing with Trolox $\left(\mathrm{IC}_{50} 0.221 \mu \mathrm{M}\right.$, ARA $\left.4.5 \mu \mathrm{M}^{-1}\right)$, the low antioxidant capacity of phenethyl derivatives 1-4 and 7-10 (ARA from $8 \times 10^{-4}$ to $4.5 \times 10^{-2} \mu \mathrm{M}^{-1}$ ) was confirmed and emphasized by the greater differences in ARA data between these compounds and catechols 5, 6 and 11, 12 (ARA from 1.99 to $8.1 \mu \mathrm{M}^{-1}$ ). Specifically, TEAC values in the ABTS assay almost doubled going from mono- to dihydroxyl derivatives, whereas ARA values of catechols were at least 40 times higher than monohydroxylated compounds in the DPPH assay. Even though no significant increase of antioxidant capacity was observed in the trifluoroacetate esters, the maintenance of antioxidant activity after esterification was another important affirmation from the in vitro data of ABTS/DPPH experiments (Figure 2, Table SI1).

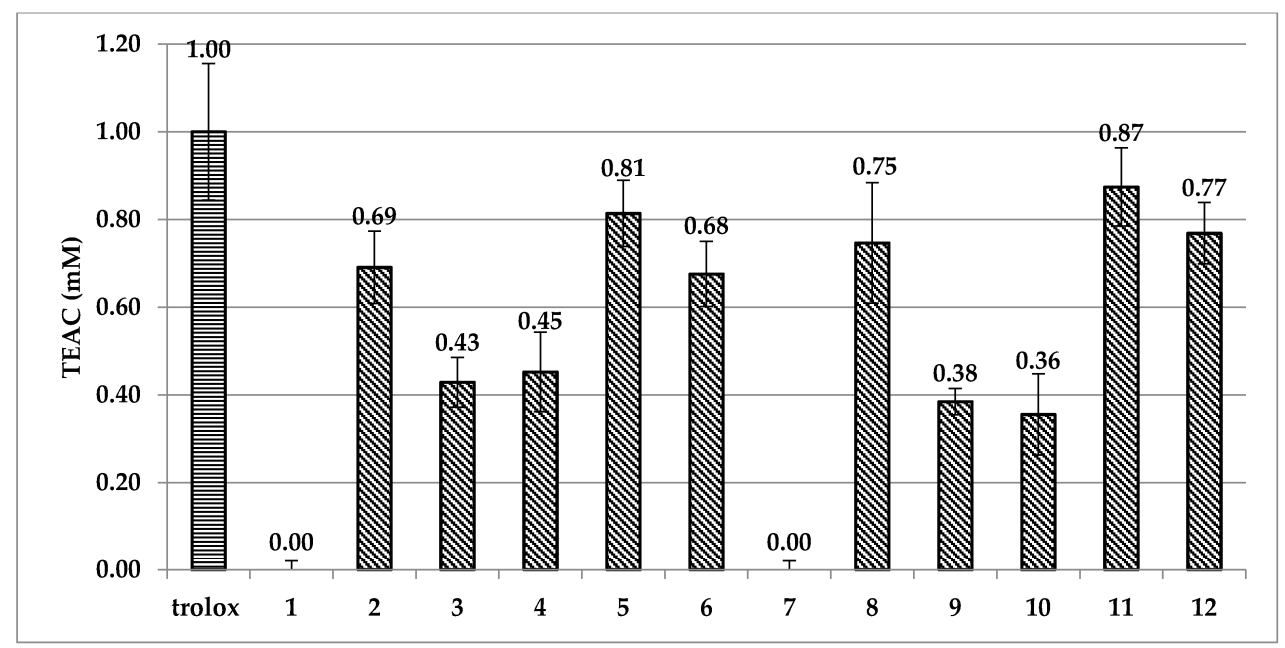

Figure 2. Trolox Equivalent Antioxidant Capacity (TEAC) values, expressed as Trolox mM equivalent, of phenethyl alcohols 1-6 and the corresponding trifluoroacetyl esters 7-12. Errors were calculated using Student's $t$ test. Statistical analysis was performed with one-way ANOVA and Bonferroni post-test, $p<0.05$. 


\subsection{ROS Determination}

The fluorometric DCF assay is a useful technique to evaluate the antioxidant activity of compounds in cells exposed to oxidative stress induced by cumene hydroperoxide. The analyses were carried out in two different cell lines particularly sensitive to radical production: L6 myoblasts from rat skeletal muscle and THP-1 human leukemic monocytes [8,9].

None of the tested compounds gave rise to fluorescence by itself, but all compounds showed an antioxidant activity higher than 70\% and between 80 and $90 \%$ for hydroxytyrosol 6 and its corresponding ester 12 (Figure 3, Table SI2). The high level of radical scavenging activity of 4-6 and their trifluoroacetate esters 10-12 was relatively easy to predict considering the general trend observed in the chemical experiments. However, the good antioxidant activity of phenethyl alcohol $\mathbf{1}$ and its ester $\mathbf{7}$ was unexpected. As stated earlier, compound $\mathbf{1}$ has been extensively studied for its antimicrobial, antiviral, and antitumor activity, which is probably related to a physicochemical action on cell membrane permeability. However, to the best of our knowledge, its antioxidant activity has not previously been investigated until now. In this distinctive molecule, the lack of phenolic groups and maintenance of an antioxidant activity supports the notion that the role of antioxidants in cells may be related not only to radical scavenging capacity but also to activation of specific metabolic pathways. Compound $\mathbf{1}$ is structurally similar to tyrosol $\mathbf{4}$ and hydroxytyrosol $\mathbf{6}$, but also to other simple neurotransmitter monoamines like dopamine. Therefore, the good antioxidant activity of $\mathbf{1}$ and its trifluoroacetyl ester $\mathbf{7}$ may be derived from its capacity to interact with specific enzymes or modulators of the antioxidant metabolic pathway, even with just a phenyl ring and alcohol group conveniently located two carbons away from the aromatic [36]. Further biological investigations in this area could be of great interest.

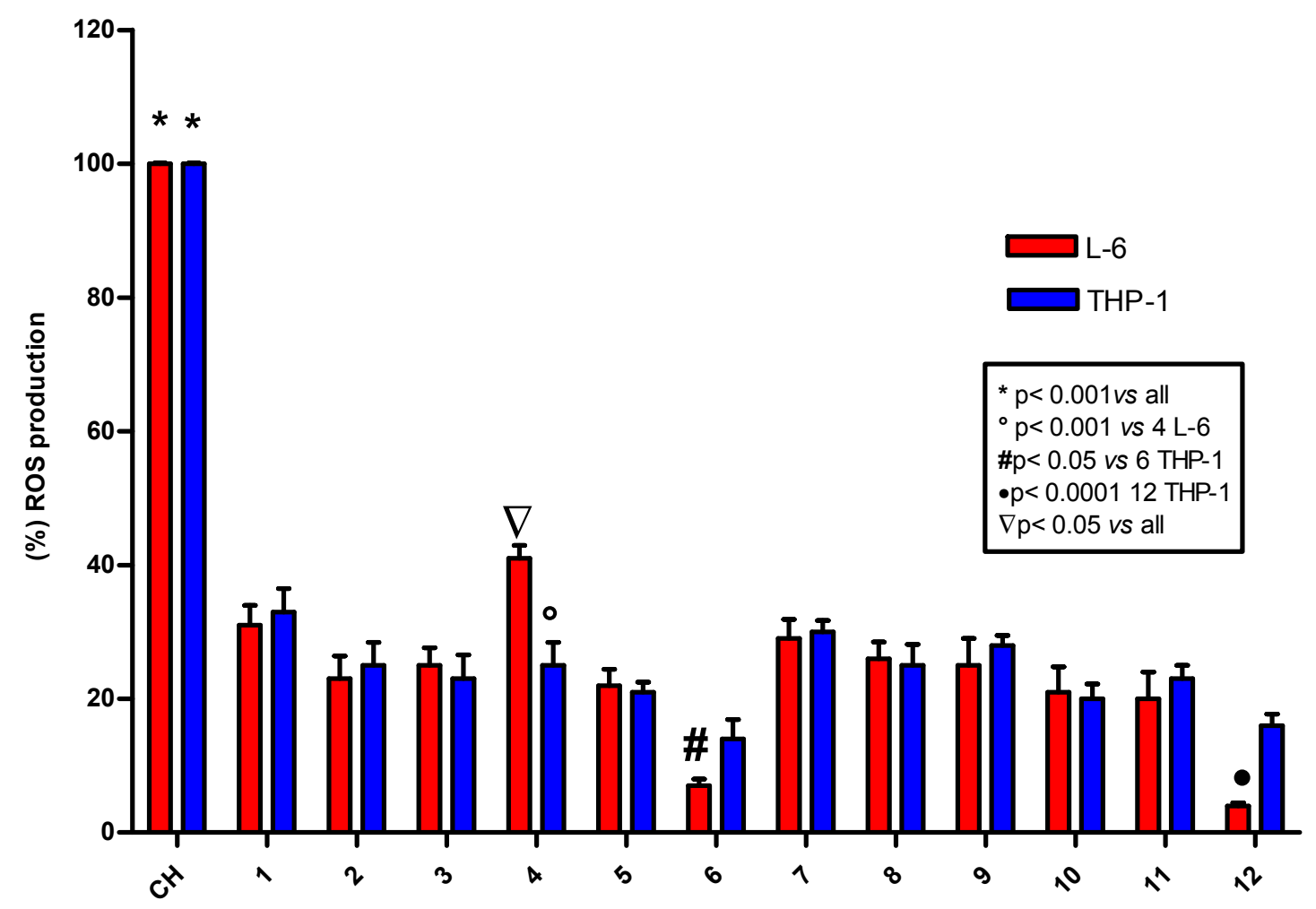

Figure 3. Determination of intracellular ROS in L6 and THP-1 cell lines after stimulation of DCF fluorescence with $200 \mu \mathrm{M}$ cumene hydroperoxide $(\mathrm{CH})$ alone or in presence of phenethyl alcohols 1-6 or the corresponding trifluoroacetate esters 7-12 at $10 \mu \mathrm{M}$ concentration. Data are reported as mean values \pm SD of five experiments carried out in triplicate. Statistical analysis performed with one-way ANOVA and Bonferroni post-test, except for 4, 6, and 12 where Student's $t$ test was used. 


\subsection{Compound Toxicity and Cell Proliferation}

Considering the good antioxidant activity observed for compounds 5, 6 and their corresponding trifluoroacetate derivatives $\mathbf{1 1}$ and 12, it was essential to check the potential toxicity on cell lines and/or their effect on proliferation for cosmetic, food and pharmaceutical applications. Furthermore, based on the unexpected cellular antioxidant activity of compounds $\mathbf{1}$ and $\mathbf{7}$, these two compounds were also included in the analyses. Employing the MTT colorimetric assay, toxicity curves were constructed using L6 myoblasts and a range of antioxidant concentrations from 10 to $40 \mu \mathrm{M}$ (Figure 4). The results revealed a low toxicity for all compounds analyzed, with cell vitality barely diminished at concentrations higher than $20 \mu \mathrm{M}$. The comparable behavior of the trifluoroacetate esters and their respective alcoholic precursors suggests that, at the concentrations used, trifluoroacetic acid produced by hydrolysis does not cause any remarkable effects in the cells. Cell proliferation experiments were performed in both cell lines (L6 and THP-1). The results demonstrated a low interference in cell proliferation by all antioxidants under study, either in the presence or absence of cumene hydroperoxide. As a representative example, the cell performances for compound $\mathbf{1}$ and its corresponding trifluoroacetate derivative 7 are shown in Figure 5. Homovanillyl alcohol 5 showed a remarkable peculiarity; it promoted L6 myoblast proliferation but inhibited THP-1 tumor cell growth (Figures SI1 and SI2).
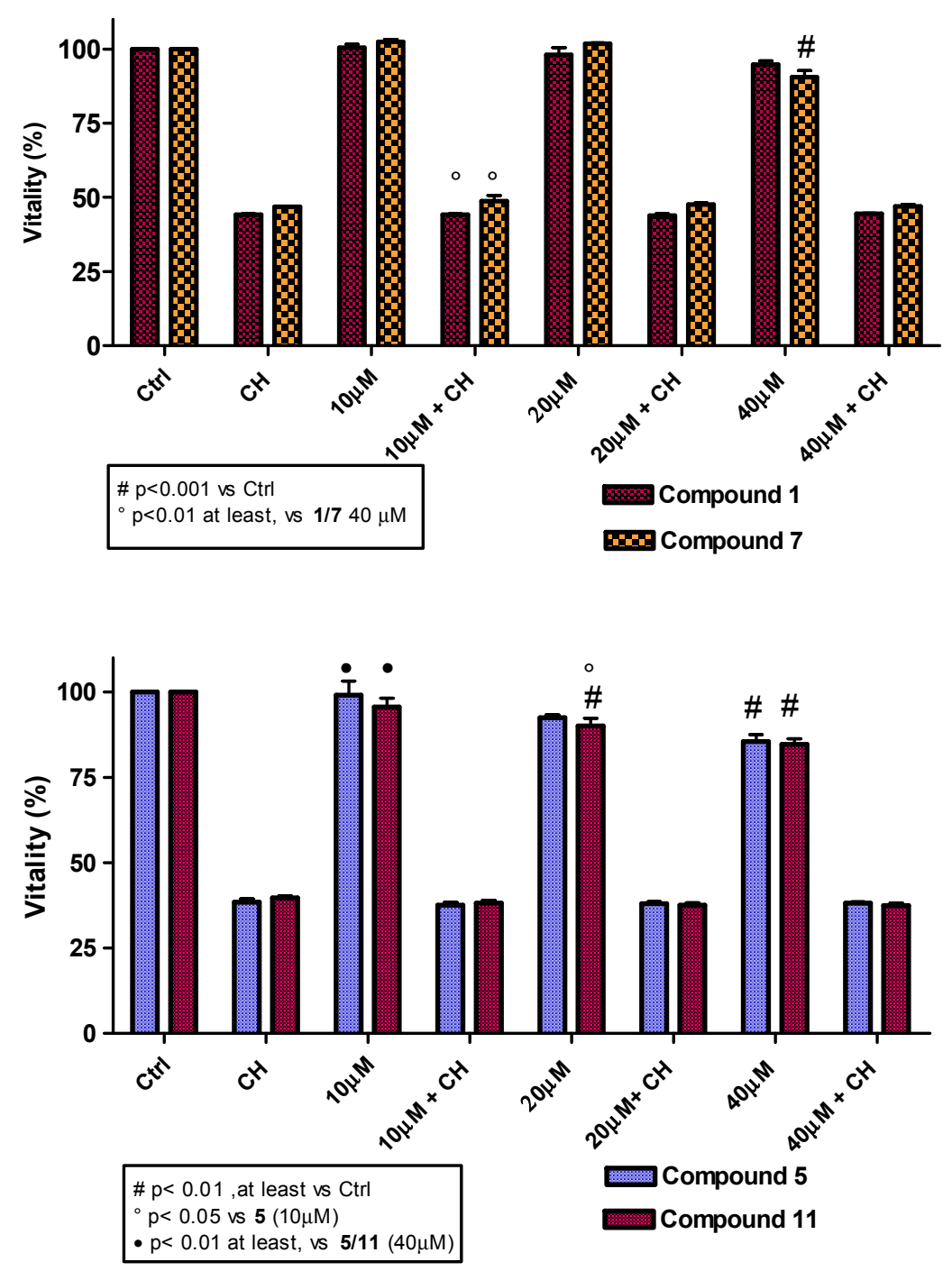

Figure 4. Cont. 


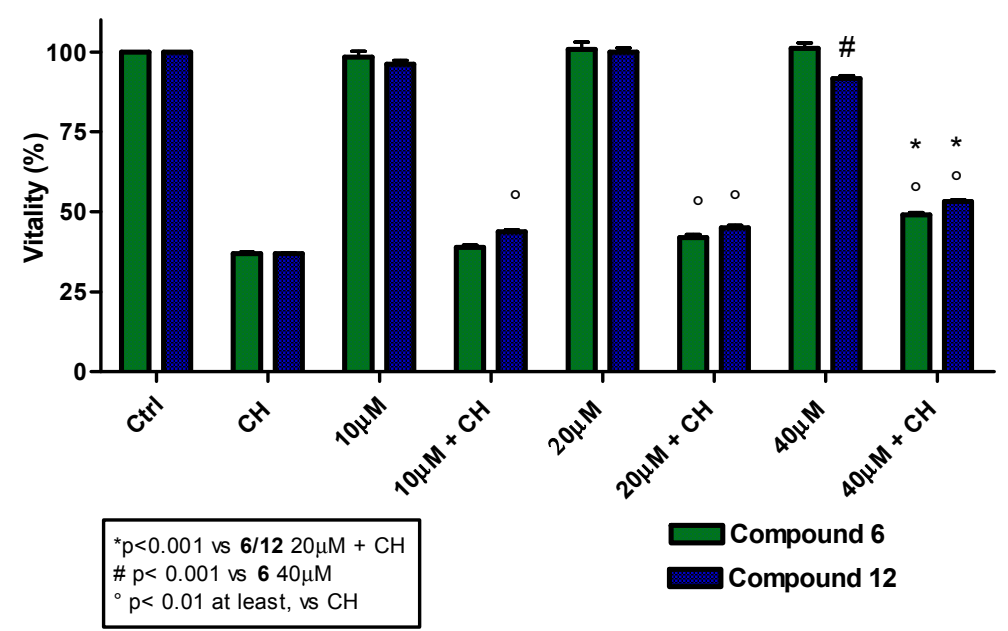

Figure 4. 3-(4,5-dimethylthiazol-2-yl)-2,5-diphenyltetrazolium bromide (MTT) spectrophotometric assay of compounds $\mathbf{1}, \mathbf{5}, \mathbf{6}, \mathbf{7}, \mathbf{1 1}, 12$ at 10 to $40 \mu \mathrm{M}$ concentration in L6 cells in presence or absence of cumene hydroperoxide $(\mathrm{CH}, 27.5 \mu \mathrm{M})$. Data are reported as mean values $\pm \mathrm{SD}$ of each compound tested in quintuplicate. Statistical analysis performed with one-way analysis of variance (ANOVA) and Bonferroni post-test. The analysis was carried out using the Prism 4 statistics program. Differences were considered significant at $p<0.05$.
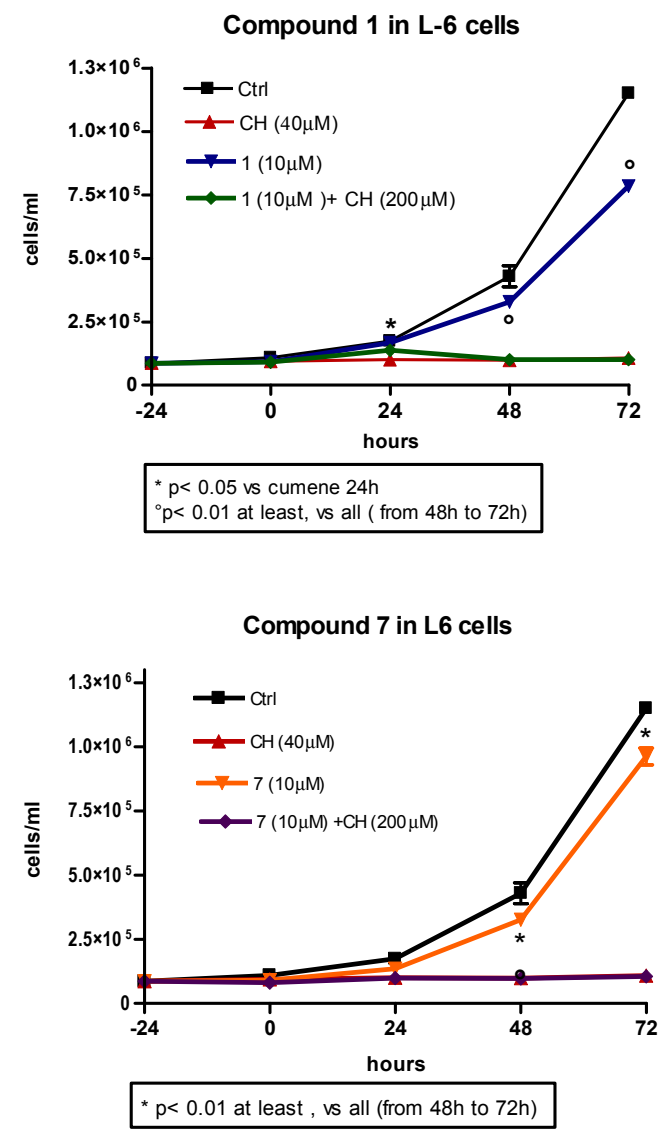
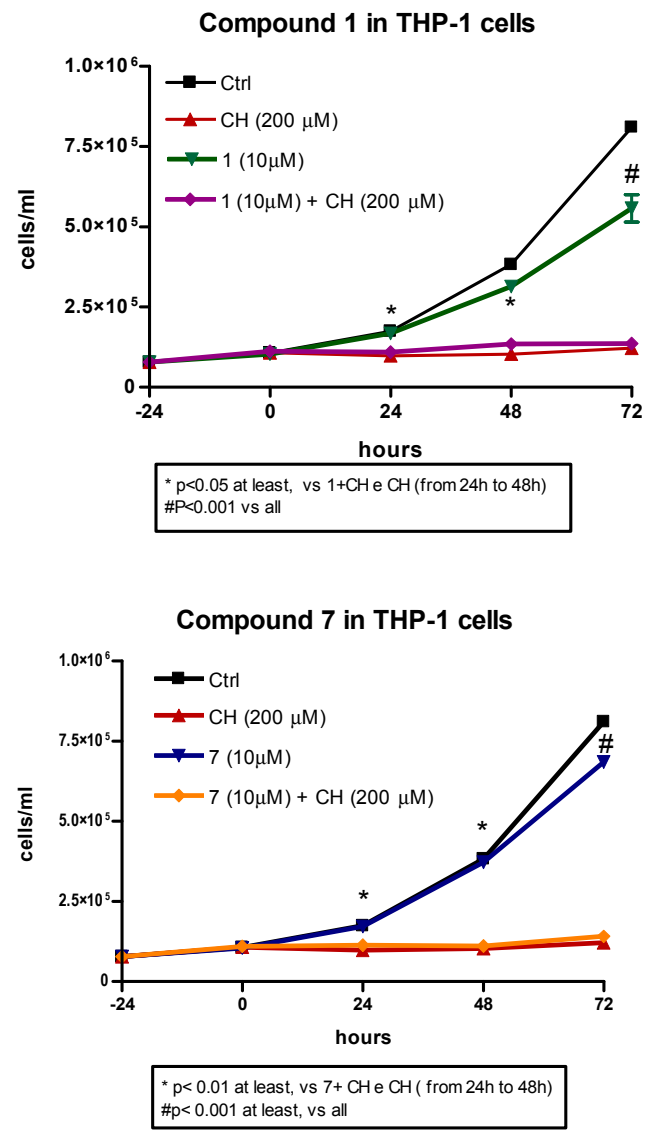

Figure 5. Effect of compound 1 and its ester $7(10 \mu \mathrm{M})$ on the proliferation of L6 and THP-1 cells in presence or absence of cumene hydroperoxide (CH, $40 \mu \mathrm{M}$ in L6 and $200 \mu \mathrm{M}$ in THP-1 cells). Cell counting was done with a Neubauer chamber. Data are reported as mean values $\pm \mathrm{SD}$ of each compound tested in duplicate. Statistical analysis performed with one-way ANOVA and Bonferroni post-test. 


\section{Materials and Methods}

\subsection{Chemicals}

All chemicals (analytical grade), silica gel 60 F254 plates, and silica gel 60 were purchased from Sigma-Aldrich (Milan, Italy). 2' $7^{\prime}$-Dichlorodihydrofluorescein diacetate ( $\left.\mathrm{DCFH}_{2}-\mathrm{DA}\right)$ was supplied by Molecular Probes (Eugene, OR, USA). Fresh pure hydroxytyrosol was synthetized in our laboratory as previously reported [37]. L6 myoblasts from rat skeletal muscle and THP-1 human leukemic monocytes were purchased from the American Type Culture Collection (Rockville, MD, USA). DMEM (Dulbecco's modified Eagle's medium), RPMI 1640, streptomycin (100 mg/mL), penicillin (100 U/mL), D-glucose, and sterile plasticware for cell culture were from Falcon (San Diego, CA, USA). Fetal bovine serum was from GIBCO (Grand Island, NY, USA).

\subsection{Instruments}

${ }^{1} \mathrm{H},{ }^{13} \mathrm{C}$, and ${ }^{19} \mathrm{~F}$ NMR spectra were recorded in deuterated solvents $\left(\mathrm{CDCl}_{3}, \mathrm{CD}_{3} \mathrm{OD} 99.8 \%\right.$ in deuterium) using a $400 \mathrm{MHz}$ nuclear resonance spectrometer (Bruker, Munich, Germany). All chemical shifts were expressed in parts per million ( $\delta$ scale) and referenced to either the residual protons or carbon of the solvent. Coupling constants, J, were reported in Hz. GC-MS analyses were carried out on a Shimadzu VG 70/250S apparatus equipped with a Supelco SLB ${ }^{\mathrm{TM}}$ column $(30 \mathrm{~m}, 0.25 \mathrm{~mm}$ and $0.25 \mu \mathrm{m}$ film thickness). The analyses were performed using an isothermal temperature profile of $100{ }^{\circ} \mathrm{C}$ for $2 \mathrm{~min}$, followed by a $10{ }^{\circ} \mathrm{C} / \mathrm{min}$ temperature gradient until $280^{\circ} \mathrm{C}$ for $15 \mathrm{~min}$. The injector temperature was $280^{\circ} \mathrm{C}$. The fluorometric analyses were performed using a VICTOR 3V Perkin Elmer spectrofluorometer (Milan, Italy).

\subsection{Synthesis of Phenethyl Trifluoroacetate Esters: General Procedure}

Phenethyl alcohol $(0.5 \mathrm{mmol})$ was dissolved in trifluoroacetic acid at room temperature $(2.0 \mathrm{~mL})$. The solution was kept under stirring at $\mathrm{T}=70{ }^{\circ} \mathrm{C}$. The reaction was monitored by thin layer chromatography (eluent: hexane/ethyl acetate $=70 / 30$ ), and after $2 \mathrm{~h}$, the substrate disappeared. Then, a saturated solution of $\mathrm{NaHCO}_{3}$ was added until neutral $\mathrm{pH}$. After extraction with ethyl acetate $(3 \times 10 \mathrm{~mL})$, the reunited organic phases were washed with a saturated solution of $\mathrm{NaCl}(2.0 \mathrm{~mL})$, dried over $\mathrm{Na}_{2} \mathrm{SO}_{4}$, and filtered. Finally, the solvent was evaporated by distillation under reduced pressure. The oily residue was purified by silica gel chromatographic column using hexane/ethyl acetate $=70 / 30$ as eluent and characterized by NMR and GC-MS analysis.

Phenethyl trifluoroacetate 7 [38]. Yield: 98\%; yellow oil; ${ }^{1} \mathrm{H}-\mathrm{NMR}\left(400 \mathrm{MHz}, \mathrm{CDCl}_{3}\right) \delta: 7.40-7.26(5 \mathrm{H}, \mathrm{m}$, $\mathrm{Ph}-\mathrm{H}), 4.58\left(2 \mathrm{H}, \mathrm{t}, J=8.0 \mathrm{~Hz}, \mathrm{OCH}_{2}\right), 3.09\left(2 \mathrm{H}, \mathrm{t}, J=8.0 \mathrm{~Hz}, \mathrm{CH}_{2}\right) ;{ }^{13} \mathrm{C}-\mathrm{NMR}\left(100 \mathrm{MHz}, \mathrm{CDCl}_{3}\right) \delta: 156.9$ $\left(J_{\mathrm{C}-\mathrm{F}}=42.0 \mathrm{~Hz}\right), 135.7,128.4,128.3,126.6,114.0\left(J_{\mathrm{C}-\mathrm{F}}=284.0 \mathrm{~Hz}\right), 67.8,34.1 ;{ }^{19} \mathrm{~F}-\mathrm{NMR}\left(376 \mathrm{MHz}, \mathrm{CDCl}_{3}\right)$

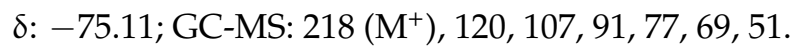

2-Hydroxyphenethyl trifluoroacetate 8. Yield: 96\%; yellow oil; ${ }^{1} \mathrm{H}-\mathrm{NMR}\left(400 \mathrm{MHz}, \mathrm{CDCl}_{3}\right) \delta: 7.19-7.15$ $(2 \mathrm{H}, \mathrm{m}, \mathrm{Ph}-\mathrm{H}), 6.94-6.91(1 \mathrm{H}, \mathrm{t}, J=8.0 \mathrm{~Hz}, \mathrm{Ph}-\mathrm{H}), 6.78(1 \mathrm{H}, \mathrm{d}, J=8.0 \mathrm{~Hz}, \mathrm{Ph}-\mathrm{H}), 4.61(2 \mathrm{H}, \mathrm{t}, J=8.0 \mathrm{~Hz}$, $\left.\mathrm{OCH}_{2}\right), 3.11\left(2 \mathrm{H}, \mathrm{t}, \mathrm{J}=8.0 \mathrm{~Hz}, \mathrm{CH}_{2}\right) ;{ }^{13} \mathrm{C}-\mathrm{NMR}\left(100 \mathrm{MHz}, \mathrm{CDCl}_{3}\right) \delta: 156.9\left(\mathrm{~J}_{\mathrm{C}-\mathrm{F}}=42.0 \mathrm{~Hz}\right), 153.3,131.0$, $127.9,122.1,120.5,116,4,114.0\left(J_{C-F}=284.0 \mathrm{~Hz}\right), 66.9,28.4 ;{ }^{19} \mathrm{~F}-\mathrm{NMR}\left(376 \mathrm{MHz} \mathrm{CDCl}_{3}\right) \delta:-75.10$. GC-MS: $234\left(\mathrm{M}^{+}\right), 120,107,91,77,69,51$.

3-Hydroxyphenethyl trifluoroacetate 9. Yield: 98\%; yellow oil; ${ }^{1} \mathrm{H}-\mathrm{NMR}\left(400 \mathrm{MHz}, \mathrm{CDCl}_{3}\right) \delta: 7.22(2 \mathrm{H}$, $\mathrm{t}, J=8.0 \mathrm{~Hz}, \mathrm{Ph}-\mathrm{H}), 6.83-6.74(3 \mathrm{H}, \mathrm{m}, \mathrm{Ph}-\mathrm{H}), 4.54\left(2 \mathrm{H}, \mathrm{t}, J=8.0 \mathrm{~Hz}, \mathrm{OCH}_{2}\right), 3.01(2 \mathrm{H}, \mathrm{t}, J=8.0 \mathrm{~Hz}$, $\left.\mathrm{CH}_{2}\right) ;{ }^{13} \mathrm{C}-\mathrm{NMR}\left(100 \mathrm{MHz}, \mathrm{CDCl}_{3}\right) \delta: 157.0\left(\mathrm{~J}_{\mathrm{C}-\mathrm{F}}=42.0 \mathrm{~Hz}\right), 156.6,137.8,129.8,120.5,115.8,114.7,114.0$ $\left(J_{\mathrm{C}-\mathrm{F}}=284.0 \mathrm{~Hz}\right), 68.3,34.4 ;{ }^{19} \mathrm{~F}-\mathrm{NMR}\left(376 \mathrm{MHz}, \mathrm{CDCl}_{3}\right) \delta:-75.09 ; \mathrm{GC}-\mathrm{MS}\left(\mathrm{M}^{+}\right): 234\left(\mathrm{M}^{+}\right), 120,107$, $91,77,69,51$.

4-Hydroxyphenethyl trifluoroacetate (tyrosol trifluoroacetate) 10. Yield: $98 \%$; yellow oil; ${ }^{1} \mathrm{H}-\mathrm{NMR}(400 \mathrm{MHz}$, $\left.\mathrm{CDCl}_{3}\right) \delta: 7.11(2 \mathrm{H}, \mathrm{t}, J=8.0 \mathrm{~Hz}, \mathrm{Ph}-\mathrm{H}), 6.82(2 \mathrm{H}, \mathrm{d}, J=8.0 \mathrm{~Hz}, \mathrm{Ph}-\mathrm{H}), 4.52\left(2 \mathrm{H}, \mathrm{t}, J=4.0 \mathrm{~Hz}, \mathrm{OCH}_{2}\right)$, 
$3.00\left(3 \mathrm{H}, \mathrm{t}, J=4.0 \mathrm{~Hz}, \mathrm{CH}_{2}\right) ;{ }^{13} \mathrm{C}-\mathrm{NMR}\left(100 \mathrm{MHz}, \mathrm{CDCl}_{3}\right) \delta: 157.0\left(J_{\mathrm{C}-\mathrm{F}}=42.0 \mathrm{~Hz}\right), 154.1,129.6,127.9$, 115.1, 114.0 (JC-F $=284.0 \mathrm{~Hz}), 68.1,33.2 ;{ }^{19} \mathrm{~F}-\mathrm{NMR}\left(376 \mathrm{MHz} \mathrm{CDCl}_{3}\right) \delta:-75.10$; GC-MS: $234\left(\mathrm{M}^{+}\right), 107$, $91,77,69,51$.

4-Hydroxy-3-methoxyphenethyl trifluoroacetate 11. Yield: $88 \%$; yellow oil; ${ }^{1} \mathrm{H}-\mathrm{NMR}\left(400 \mathrm{MHz}, \mathrm{CDCl}_{3}\right)$ $\delta: 6.89(1 \mathrm{H}, \mathrm{d}, J=8.0 \mathrm{~Hz}, \mathrm{Ph}-\mathrm{H}), 6.73-6.70(2 \mathrm{H}, \mathrm{m}, \mathrm{Ph}-\mathrm{H}), 4.53\left(2 \mathrm{H}, \mathrm{t}, J=8.0 \mathrm{~Hz}, \mathrm{OCH}_{2}\right), 3.90(3 \mathrm{H}, \mathrm{s}$, $\left.\mathrm{OCH}_{3}\right), 3.00\left(2 \mathrm{H}, \mathrm{t}, J=8.0 \mathrm{~Hz}, \mathrm{CH}_{2}\right) ;{ }^{13} \mathrm{C}-\mathrm{NMR}\left(100 \mathrm{MHz}, \mathrm{CDCl}_{3}\right) \delta: 156.9\left(\mathrm{~J}_{\mathrm{C}-\mathrm{F}}=42.0 \mathrm{~Hz}\right), 146.6,144.7$, 128.0, 121.6, 114.6, $114.0\left(\mathrm{~J}_{\mathrm{C}-\mathrm{F}}=284.0 \mathrm{~Hz}\right), 111.4,68.2,55.8,34.3 ;{ }^{19} \mathrm{~F}-\mathrm{NMR}\left(376 \mathrm{MHz}, \mathrm{CDCl}_{3}\right)$ 8: -75.10 . GC-MS: $264\left(\mathrm{M}^{+}\right), 150,137,122,107,91,77,69,51$.

3,4-Dihydroxyphenethyl trifluoroacetate (hydroxytyrosol trifluoroacetate) 12. Yield. 85\%; yellow oil; ${ }^{1} \mathrm{H}-\mathrm{NMR}$ $\left(400 \mathrm{MHz}, \mathrm{CD}_{3} \mathrm{COCD}_{3}\right) \delta: 6.83(1 \mathrm{H}, \mathrm{d}, J=8.0 \mathrm{~Hz}, \mathrm{Ph}-\mathrm{H}), 6.78-6.65(2 \mathrm{H}, \mathrm{m}, \mathrm{Ph}-\mathrm{H}), 4.49(2 \mathrm{H}, \mathrm{t}, J=8.0 \mathrm{~Hz}$, $\left.\mathrm{OCH}_{2}\right), 2.93\left(2 \mathrm{H}, \mathrm{t}, J=8.0 \mathrm{~Hz}, \mathrm{CH}_{2}\right) ;{ }^{13} \mathrm{C}-\mathrm{NMR}\left(100 \mathrm{MHz}, \mathrm{CD}_{3} \mathrm{COCD}_{3}\right) \delta: 157.0\left(J_{\mathrm{C}-\mathrm{F}}=42.0 \mathrm{~Hz}\right), 143.8$, 142.6, 129.1, 121.4, 115.8, 115.6, $114.0\left(J_{\mathrm{C}-\mathrm{F}}=284.0 \mathrm{~Hz}\right), 68.5,33.9 ;{ }^{19} \mathrm{~F}-\mathrm{NMR}\left(376 \mathrm{MHz}, \mathrm{CD}_{3} \mathrm{COCD}_{3}\right)$ ס: -75.09; GC-MS: $250\left(\mathrm{M}^{+}\right), 136,123,107,91,77,69,51$.

\subsection{Measurement of Partition Coefficient $(\log P)$}

The $\log \mathrm{P}$ value of all compounds was determined as reported in the literature by UV-Vis spectrophotometry [35]. The partition coefficient $(\log \mathrm{P})$ was calculated according to the following relationship: $\log \mathrm{P}=\log \mathrm{A}_{x} /\left(\mathrm{A}_{0}-\mathrm{A}_{\mathrm{x}}\right)$. $\mathrm{A}_{0}$ was the maximum of absorbance of a solution $0.15 \mathrm{mM}$ of each compound dissolved in 1-octanol; $\mathrm{A}_{\mathrm{x}}$ is the maximum of absorbance of the organic solution containing the compound after separation from the phosphate buffer $(0.1 \mathrm{M}, \mathrm{pH} 7.4)$ solution. A solution of 1-octanol saturated with the buffer was used as a blank. Experimental $\log \mathrm{P}$ values are reported in Table 1.

\subsection{ABTS Assay}

The antioxidant capacity of compounds 1-12 was measured according to the method of Pellegrini et al. [39] but working at room temperature [8,9]. 6-Hydroxy-2,5,7,8-tetramethylchroman-2-carboxylic acid (Trolox) was used as reference. The analyses were carried out in ethanol $(0.2 \%$ of water) at room temperature and the absorbance was measured at $\lambda=734 \mathrm{~nm}$. Each sample $(1.0 \mathrm{~mL})$ of ABTS $^{+\bullet}$ was obtained from the aqueous mother solution by dilution with ethanol to an absorbance of $0.70 \pm 0.20$, and $10 \mu \mathrm{L}$ of the ethanol solution of the antioxidant was added. All compounds were analyzed at four different final concentrations ranging from 1 to $10 \mu \mathrm{M}$. The absorbance was measured after $2 \mathrm{~min}$. Four measurements were recorded for each concentration. Each time blanks of pure solvent were run. The standard deviations of data were all below $5 \%$. The dose-response curves were expressed as the percentage of absorbance decrease (ABTS inhibition expressed as percentage) against the amount of antioxidant concentration. Linear regression was conducted using GraphPad Prism 4.01 (2004) software. The antioxidant capacities were extrapolated at $10 \mu \mathrm{M}$ concentration and reported as Trolox Equivalent Antioxidant Capacity (TEAC), defined as the concentration $(\mathrm{mmol} / \mathrm{L})$ of Trolox having the antioxidant capacity equivalent to that of a $1.0 \mathrm{mmol} / \mathrm{L}$ solution of the substance under investigation. Results are expressed as mean \pm standard deviation. Statistical analyses were performed using the Student's $t$ test. The level of significance was $p<0.05$ for all data.

\subsection{DPPH Assay}

DPPH assay was performed following the method described by Brand-Williams et al. [40] with some modifications. A $75 \mu \mathrm{M}$ solution of DPPH in methanol was prepared. Samples were diluted and analyzed at three different final concentrations ranging from 1 to $10 \mu \mathrm{M}$. A $50 \mu \mathrm{L}$ volume of each sample solution was added to $0.950 \mathrm{~mL}$ of DPPH solution and left in the dark. After $30 \mathrm{~min}$, the absorbance of samples was measured at $\lambda=517 \mathrm{~nm}$. For the blank, $50 \mu \mathrm{L}$ of pure ethanol was used. Four measurements were recorded for each sample. Data collected showed a standard deviation below $5 \%$. Percentages of DPPH inhibition versus antioxidant concentrations were plotted. Linear regressions 
were conducted using GraphPad Prism 4 software. $\mathrm{IC}_{50}$ values were extrapolated from each graph as the concentration of sample that decreases by 50\% DPPH radical absorbance. Statistical analyses were performed by the Student's $t$ test and one-way analysis of variance (ANOVA). Lastly, anti-radical activity (ARA), as the inverse of $\mathrm{IC}_{50}$, was also calculated.

\subsection{Cells in Culture}

L6 myoblasts were seeded in $75-\mathrm{cm}^{2}$ tissue culture flasks and grown in DMEM containing $4.5 \mathrm{~g} / \mathrm{L}$ glucose, supplemented with $10 \%$ heat-inactivated fetal bovine serum, $100 \mu \mathrm{g} / \mathrm{mL}$ streptomycin, and $100 \mathrm{U} / \mathrm{mL}$ penicillin, in an atmosphere of $5 \% \mathrm{CO}_{2}$ at $37^{\circ} \mathrm{C}$. Cells reached confluency after five days (approximately $6.0 \times 10^{6}$ cells / flask) and were kept in culture as myoblasts by continuous passages at preconfluent stages as previously reported [41]. THP-1 human leukemic monocytes were grown in suspension in RPMI 1640 medium with 10\% fetal bovine serum, $100 \mu \mathrm{g} / \mathrm{mL}$ streptomycin, and $100 \mathrm{U} / \mathrm{mL}$ penicillin, in a humidified atmosphere with $5 \% \mathrm{CO}_{2}$ at $37{ }^{\circ} \mathrm{C}$ [42]. THP-1 monocytes were passaged twice a week by 1:4 dilutions and re-seeded; cells from passages 7-23 were used for the experiments.

\subsection{Intracellular ROS Determination}

The antioxidant activity of each compound was measured by a standard intracellular fluorescent probe (DCF) assay [8,9,41,42] using L6 myoblasts and THP-1 monocytes exposed to oxidative stress by the addition of cumene hydroperoxide, a radical generator. Fluorescence was measured over a 10-min period, and the ability of the compounds to eliminate the increased ROS production was determined. For L6 myoblasts, growing attached to the bottom of the flask, the medium was discarded and cells were washed twice with $5 \mathrm{~mL}$ phosphate buffered saline (PBS) containing $5.0 \mathrm{mM}$ glucose (PBS-glucose) at $37^{\circ} \mathrm{C}$. Cells were gently scraped off with PBS-glucose at $37^{\circ} \mathrm{C}$ and centrifuged at $1200 \mathrm{rpm}$ for $5 \mathrm{~min}$ (approximately $100 \times \mathrm{g}$ ). The supernatant was discarded and the pellet resuspended in PBS-glucose. Incubation with the probe $\mathrm{DCFH}_{2}$-DA at a final concentration of $10 \mu \mathrm{M}$ (from a stock solution of $10 \mathrm{mM}$ in DMSO) was carried out for $30 \mathrm{~min}$ at $37{ }^{\circ} \mathrm{C}$ in the dark. At the end of the incubation, cells were washed twice, centrifuged at $1200 \mathrm{rpm}$ for $5 \mathrm{~min}$, and the final cell pellet was resuspended in PBS-glucose. Before the experiment was initiated, cells were allowed to recover for $1 \mathrm{~h}$ at room temperature in the dark. The THP-1 monocytes, growing in suspension, were centrifuged at $1200 \mathrm{rpm}$ for $10 \mathrm{~min}$. The supernatant was discarded, and cells were washed twice with $5 \mathrm{~mL}$ PBS-glucose at $37^{\circ} \mathrm{C}$ to remove the serum. The pellet was successively resuspended in PBS-glucose, and the probe $\mathrm{DCFH}_{2}$-DA was added at $10 \mu \mathrm{M}$ final concentration. From that point onwards, the protocols for the two cell types were identical. Intracellular fluorescence was measured at $37{ }^{\circ} \mathrm{C}$ using a Perkin Elmer VICTOR 3V spectrofluorometer (excitation at $\lambda=498 \mathrm{~nm}$ and emission at $\lambda=530 \mathrm{~nm}$ ). Cumene hydroperoxide in DMSO was used as the radical generator (200 $\mu \mathrm{M}$ final concentration); DMSO did not affect the fluorescence signal at the concentrations used. Cells were incubated with compounds at the final designated concentration for $10 \mathrm{~min}$ at $37^{\circ} \mathrm{C}$ before addition of the radical generator. The decrease in the intracellular DCF fluorescence relative to the fluorescence change induced by $200 \mu \mathrm{M}$ cumene hydroperoxide alone $(100 \%)$, reported as $\Delta \mathrm{F} / 10 \mathrm{~min}$, determined the antioxidant activities. Data are reported as the mean \pm standard deviation of at least four different experiments carried out in triplicate. One-way ANOVA test (non-parametric) and Bonferroni post-test (comparing all pairs of columns) were used for the statistical analyses.

\subsection{MTT Assay}

The 3-(4,5-dimethylthiazol-2-yl)-2,5-diphenyltetrazolium bromide (MTT) spectrophotometric assay assessed proliferation/cytotoxicity. Compounds 1, 5-7, 11, and 12 (1.0 mM) were tested and diluted in either DMEM or RPMI, supplemented as detailed above for the two cell types, to final concentrations of 10, 20, and $40 \mu \mathrm{M}$. L6 cells treated with and without cumene hydroperoxide $(27.5 \mu \mathrm{M})$ [41] were seeded at a density of 10,000/well in $200 \mu \mathrm{L}$ of complete medium in a 96-well plate. 
After $24 \mathrm{~h}$, the DMEM was discarded and $100 \mu \mathrm{L}$ of the test solutions was added. Following $24 \mathrm{~h}$ of incubation, $10 \mu \mathrm{L}$ of MTT solution $(5 \mathrm{mg} / \mathrm{mL})$ was added to each well and incubated for a further $4 \mathrm{~h}$. Lysis buffer was prepared by dissolving $40 \%(w / v)$ sodium dodecyl sulfate (SDS) in deionized water, mixing an equal volume of $\mathrm{N}, \mathrm{N}$-dimethylformamide with the SDS solution, and adjusting the $\mathrm{pH}$ to 4.7 [42]. After incubation with MTT, $100 \mu \mathrm{L}$ of lysis buffer was added to each well and the absorbance read at $\lambda=590 \mathrm{~nm}$ in a microplate reader (Perkin Elmer VICTOR 3V spectrometer). Each compound was tested in quintuplicate.

\subsection{Proliferation Curves}

L6 cells were seeded in $60 \times 15 \mathrm{~mm}$ Petri dishes in $4 \mathrm{~mL}$ of the complete growth medium at a density of approximately $10^{5}$ cells/well. The following day, the cells were exposed to the selected compounds 1, 5-7, 11, and 12 at a final concentration of $10 \mu \mathrm{M}$ in the absence and presence of cumene hydroperoxide $(40 \mu \mathrm{M})$. Cell counts using a Neubauer chamber were made every $24 \mathrm{~h}$ up to confluence. Each time the L6 myoblasts had to be counted, they first underwent a mild trypsinization. THP-1 cells were seeded in 24-well plates in $1 \mathrm{~mL}$ of the growth medium. After $24 \mathrm{~h}$, the cells were exposed to $10 \mu \mathrm{M}$ of the same compounds in the absence and presence of cumene hydroperoxide $(200 \mu \mathrm{M})$ and incubated for an additional $24 \mathrm{~h}$. Cell counts using a Neubauer chamber were made every $24 \mathrm{~h}$ up to confluence. The results are given as the mean \pm standard deviation of two different experiments.

\subsection{Statistical Analysis}

All data obtained from cultured cells were analyzed by one-way ANOVA and Bonferroni post-test. In some cases, the Student's $t$ test was applied. Analyses were carried out using the GraphPad Prism 4.1 statistics program. Differences were considered significant at $p<0.05$.

\section{Conclusions}

Novel trifluoroacetate esters $\mathbf{7 - 1 2}$ were prepared in high yield by a simple and efficient procedure from phenethyl alcohols 1-6 in the presence of trifluoroacetic acid. Following lipophilicity evaluation, the antioxidant activity of all compounds was tested in vitro by ABTS, DPPH assays and in cell lines by the DFC assay. Cell toxicity and proliferation were also assessed. The experimental data confirmed the direct correlation between the number of phenolic groups on the aromatic ring and the radical scavenging ability. In particular, in in vitro experiments, all trifluoroacetate esters showed a similar antioxidant activity to their corresponding alcoholic precursor, while in cellular experiments, they demonstrated a weakly enhanced performance due to their higher lipophilicity. The rationale for the good antioxidant activity of phenethyl alcohol 1 and its trifluoroacetate ester $\mathbf{7}$ in the cellular environment lies beyond these considerations and may only be explained in the context of a more general analysis of the metabolic activity of this class of compounds. Specifically, their effectiveness in the cellular environment could be due to the attachment of the hydroxyl groups by cytochrome P450, as previously reported for other molecules [43]. This interesting concept will be the subject of future work in our laboratories.

Supplementary Materials: The following are available online. Table SI1. DPPH assay of phenethyl alcohols 1-6 and trifluoroacetyl esters 7-12. Table SI2. DCF assay: determination of intracellular ROS after stimulation with cumene hydroperoxide $(\mathrm{CH})$ in presence of phenethyl alcohols 1-6 and their trifluoroacetyl esters 7-12 at $10 \mu \mathrm{M}$ concentration on both cell lines L6 and THP-1. Data are reported as mean values \pm SD of five experiments. Figure SI1. Effect of 5 and $\mathbf{1 1}(10 \mu \mathrm{M})$ on the proliferation of L6 and THP-1 cells in the absence and presence of cumene hydroperoxide (CH: $40 \mu \mathrm{M}$ in L6 and $200 \mu \mathrm{M}$ in THP-1 cells, respectively). Cell counting was done with a Neubauer Chamber. Figure SI2. Effect of 6 and $12(10 \mu \mathrm{M})$ on the proliferation of L6 and THP-1 cells in the absence and presence of cumene hydroperoxide (CH: $40 \mu \mathrm{M}$ in L6 and $200 \mu \mathrm{M}$ in THP-1 cells, respectively). Cell counting was done with a Neubauer Chamber.

Author Contributions: R.B. designed the research study and contributed to the data interpretation and to the manuscript drafting and revisions. M.B., V.C., and I.C. performed the synthesis and characterization of novel compounds. R.A.C. carried out the antioxidant assays. P.L. and S.I. analyzed the experimental data. D.T. was involved in the conception of the research study, analyzed the data, and contributed to writing the manuscript. 
Conflicts of Interest: The authors declare no conflict of interest.

\section{References}

1. Lobo, V.; Patil, A.; Phatak, A.; Chandra, N. Free radicals, antioxidants and functional foods: Impact on human health. Pharmacogn. Rev. 2010, 4, 118-126. [CrossRef] [PubMed]

2. Pollio, A.; Zarrelli, A.; Romanucci, V.; Di Mauro, A.; Barra, F.; Pinto, G.; Crescenzi, E.; Roscetto, E.; Palumbo, G. Polyphenolic profile and targeted bioactivity of methanolic extracts from Mediterranean ethnomedicinal plants on human cancer cell lines. Molecules 2016, 21, 395. [CrossRef] [PubMed]

3. D'Abrosca, B.; DellaGreca, M.; Fiorentino, A.; Monaco, P.; Zarrelli, A. Low molecular weight phenols from the bioactive aqueous fraction of Cestrum parqui. J. Agric. Food Chem. 2004, 52, 4101-4108. [CrossRef] [PubMed]

4. Saladino, R.; Crestini, C.; Bernini, R.; Mincione, E.; Ciafrino, R. A new and efficient synthesis of 8-hydroxypurine derivatives by dimethyldioxirane oxidation. Tetrahedron Lett. 1995, 36, 2665-2668. [CrossRef]

5. Saladino, R.; Bernini, R.; Crestini, C.; Mincione, E.; Bergamini, A.; Marini, S.; Palamara, A.T. Studies on the chemistry of pyrimidine derivatives with dimethyldioxirane: Synthesis, cytotoxic effects and antiviral activity of new 5,6-oxiranyl-5,5-dihydro and 5-hydroxy-5,6-dihydro-6-substitued uracil derivatives and pyrimidine nucleosides. Tetrahedron 1995, 51, 7561-7578. [CrossRef]

6. Shibutami, S.; Takeshita, M.; Grollman, A.P. Insertion of specific bases during DNA synthesis past the oxidation-damaged base 8-oxodG. Nature 1991, 349, 431-434. [CrossRef] [PubMed]

7. Bouallagui, Z.; Bouaziz, M.; Lassoued, S.; Engasser, J.M.; Ghoul, M.; Sayadi, S. Hydroxytyrosol acyl esters: Biosynthesis and activities. Appl. Biochem. Biotechnol. 2011, 163, 592-599. [CrossRef] [PubMed]

8. Tofani, D.; Balducci, V.; Gasperi, T.; Incerpi, S.; Gambacorta, A. Fatty acid hydroxytyrosyl esters: Structure/antioxidant activity relationship by ABTS and in cell-culture DCF assays. J. Agric. Food Chem. 2010, 58, 5292-5299. [CrossRef] [PubMed]

9. Bernini, R.; Crisante, F.; Barontini, M.; Tofani, D.; Balducci, V.; Gambacorta, A. Synthesis and structure/antioxidant activity relationship of novel catecholic antioxidant structural analogues to hydroxytyrosol and its lipophilic esters. J. Agric. Food Chem. 2012, 60, 7408-7416. [CrossRef] [PubMed]

10. Bernini, R.; Carastro, I.; Palmini, G.; Tanini, A.; Zonefrati, R.; Pinelli, P.; Brandi, M.L.; Romani, A. Lipophilization of hydroxytyrosol-enriched fractions from Olea europaea L. by-products and evaluation of the in vitro effects on a model of colorectal cancer cells. J. Agric. Food Chem. 2017, 65, 6506-6512. [CrossRef] [PubMed]

11. Bernini, R.; Gilardini Montani, M.S.; Merendino, N.; Romani, A.; Velotti, F. Hydroxytyrosol-derived compounds: A basis for the creation of new pharmacological agents for cancer prevention and therapy. J. Med. Chem. 2015, 58, 9089-9107. [CrossRef] [PubMed]

12. Madrona, A.; Pereira-Caro, G.; Mateos, R.; Rodriguez, G.; Trujillo, M.; Fernadez-Bolanos, J.; Espartero, J.L. Synthesis of hydroxytyrosyl alkyl ethers from olive oil waste waters. Molecules 2009, 14, 1762-1772. [CrossRef] [PubMed]

13. Gerebtzoff, G.; Li-Blatter, X.; Fischer, H.; Frentzel, A.; Seelig, A. Halogenation of drugs enhances membrane binding and permeation. Chembiochem 2004, 5, 676-684. [CrossRef] [PubMed]

14. Ismail, F.M.D. Important fluorinated drugs in experimental and clinical use. J. Fluor. Chem. 2002, 118, $27-33$. [CrossRef]

15. Bovicelli, P.; Mincione, E.; Antonioletti, R.; Bernini, R.; Colombari, M. Selective halogenation of aromatics by dimethyldioxirane and halogen ions. Synth. Commun. 2001, 31, 2955-2963. [CrossRef]

16. Bovicelli, P.; Bernini, R.; Antonioletti, R.; Mincione, E. Selective halogenation of flavanones. Tetrahedron Lett. 2002, 43, 5563-5567. [CrossRef]

17. Bernini, R.; Pasqualetti, M.; Provenzano, G.; Tempesta, S. Ecofriendly synthesis of halogenated flavonoids and evaluation of their antifungal activity. New J. Chem. 2015, 39, 2980-2987. [CrossRef]

18. Strunekà, A.; Patočka, J.; Connet, P. Fluorine in medicine. J. Appl. Biomed. 2004, 2, 141-150.

19. Zaldini Hernandes, M.; Cavalcanti, S.M.T.; Moreira, D.R.M.; Filgueira de Azevedo Junior, W.; Leite, A.C.L. Halogen atoms in the modern medicinal chemistry: Hints for the drug design. Curr. Drug Targets 2010, 11, 303-314. [CrossRef] [PubMed] 
20. Barontini, M.; Bernini, R.; Carastro, I.; Gentili, P.; Romani, A. Synthesis and DPPH radical scavenging activity of novel compounds obtained from tyrosol and cinnamic acid derivatives. New J. Chem. 2014, 38, 809-816. [CrossRef]

21. Bernini, R.; Crisante, F.; D'Acunzo, F.; Gentili, P.; Ussia, E. Oxidative cleavage of 1-aryl-isochroman derivatives by the Trametes villosa laccase/1-hydroxybenzotroazole system. New J. Chem. 2016, 40, 3314-3322. [CrossRef]

22. Loizo, M.; Bonesi, M.; Di Lecce, G.; Boselli, E.; Tundis, R.; Pugliese, A.; Menichini, F.; Frega, N.G. Phenolics, aroma profile, and in vitro antioxidant activity of Italian dessert passito wine from Saracena (Italy). J. Food Sci. 2013, 78, C703-C708. [CrossRef] [PubMed]

23. Cosmeticinfo.org. Available online: http://www.cosmeticsinfo.org/ingredient/phenethyl-alcohol-0 (accessed on 18 December 2017).

24. U.S. Food and Drug Administration. Available online: https://www.fda.gov/Food/IngredientsPackagingLabeling/ GRAS/default.htm (accessed on 18 December 2017).

25. Zhu, Y.J.; Zhou, H.T.; Hu, Y.H.; Tang, J.Y.; Su, M.X.; Guo, Y.J.; Chen, Q.X.; Liu, B. Antityrosinase and antimicrobial activities of 2-phenylethanol, 2-phenylacetaldehyde and 2-phenylacetic acid. Food Chem. 2011, 124, 298-302. [CrossRef]

26. Müller, W.E.G.; Falke, D.; Heicke, B.; Zahn, R.K. Biological activity of 2-phenylethanol and its derivatives VIII. Influence on Herpes virus DNA-synthesis in rabbit kidney cells. Arch. Virol. 1973, 40, 205-214.

27. Brossmer, R.; Bohn, B.; Schlicker, H. Influence of 2-phenylethanol and 1,1'-dimethylphenyl-ethanol on metabolic activity and cell membrane function in Ehrlich ascites tumour cells. FEBS Lett. 1973, 35, 191-194. [CrossRef]

28. Romani, A.; Pinelli, P.; Ieri, F.; Bernini, R. Sustainability, innovation and green chemistry in the production and valorization of phenolic extracts from Olea europaea L. Sustainability 2016, 8, 1002. [CrossRef]

29. Bernini, R.; Merendino, N.; Romani, A.; Velotti, F. Naturally occurring hydroxytyrosol: Synthesis and anticancer potential. Curr. Med. Chem. 2013, 20, 655-670. [CrossRef] [PubMed]

30. Bernini, R.; Cacchi, S.; Fabrizi, G.; Filisti, E. 2-Arylhydroxytyrosol derivatives via Suzuki-Miyaura cross-coupling. Org. Lett. 2008, 10, 3457-3460. [CrossRef] [PubMed]

31. Bernini, R.; Crisante, F.; Merendino, N.; Molinari, R.; Soldatelli, M.C.; Velotti, F. Synthesis of a novel ester of hydroxytyrosol and alpha-lipoic acid exhibiting an antiproliferative effect on human colon cancer HT-29 cells. Eur. J. Med. Chem. 2011, 46, 439-446. [CrossRef] [PubMed]

32. Fortunati, E.; Luzi, F.; Dugo, L.; Fanali, C.; Tripodo, G.; Santi, L.; Kenny, J.M.; Torre, L.; Bernini, R. Hydroxytyrosol as active ingredient in poly(vinyl alcohol) films for food packaging applications. J. Renew. Mater. 2017, 5, 81-95. [CrossRef]

33. Fortunati, E.; Luzi, F.; Dugo, L.; Fanali, C.; Tripodo, G.; Santi, L.; Kenny, J.M.; Torre, L.; Bernini, R. Effect of hydroxytyrosol methyl carbonate on the thermal, migration and antioxidant properties of PVA based films for active food packaging. Polym. Int. 2016, 65, 872-882. [CrossRef]

34. Bernini, R.; Mincione, E.; Crisante, F.; Barontini, M.; Fabrizi, G.; Gentili, P. Chemoselective and efficient carboxymethylation of the alcoholic chain of phenols by dimethyl carbonate (DMC). Tetrahedron Lett. 2007, 48, 7000-7003. [CrossRef]

35. Grasso, S.; Siracusa, L.; Spatafora, C.; Renis, M.; Tringali, C. Hydroxytyrosol lipophilic analogues: Enzymatic synthesis, radical scavenging activity and DNA oxidative damage protection. Bioorg. Chem. 2007, 35, 137-152. [CrossRef] [PubMed]

36. Leone, S.; Fiore, M.; Lauro, M.G.; Pino, S.; Cornetta, T.; Cozzi, R. Resveratrol and X rays affect gap junction intercellular communications in human glioblastoma cells. Mol. Carcinog. 2008, 47, 587-598. [CrossRef] [PubMed]

37. Bernini, R.; Mincione, E.; Barontini, M.; Crisante, F. Convenient synthesis of hydroxytyrosol and its lipophilic derivatives from tyrosol or homovanillyl alcohol. J. Agric. Food Chem. 2008, 56, 8897-8904. [CrossRef] [PubMed]

38. Chen, C.-T.; Kuo, J.-H.; Pawar, V.D.; Munot, Y.S.; Weng, S.-S.; Ku, C.-H.; Liu, C.-Y. Nucleophilic acyl substitutions of anhydrides with protic nucleophiles catalyzed by amphoteric, oxomolybdenum species. J. Org. Chem. 2005, 70, 1188-1197. [CrossRef] [PubMed]

39. Pellegrini, N.; Visioli, F.; Buratti, S.; Brighenti, F. Direct analysis of total antioxidant activity of olive oil and studies on the influence of heating. J. Agric. Food Chem. 2001, 49, 2532-2538. [CrossRef] [PubMed] 
40. Brand-Williams, W.; Cuvelier, M.E.; Berset, C. Use of free radical method to evaluate antioxidant activity. Lebensm. Wiss. Technol. 1995, 28, 25-30.

41. D’Arezzo, S.; Incerpi, S.; Davis, F.B.; Acconcia, F.; Marino, F.; Farías, R.N.; Davis, P.J. Rapid nongenomic effects of 3,5,3'-triiodo L-thyronine on the intracellular $\mathrm{pH}$ of L-6 myoblasts are mediated by intracellular calcium mobilization and kinase pathways. Endocrinology 2004, 145, 5694-5703. [CrossRef] [PubMed]

42. Lombardo, E.; Sabellico, C.; Hájek, J.; Staňková, V.; Filipský, T.; Balducci, V.; De Vito, P.; Leone, S.; Bavavea, E.I.; Proietti Silvestri, I.; et al. Protection of cells against oxidative stress by nanomolar levels of hydroxyflavones indicates a new type of intracellular antioxidant mechanism. PLoS ONE 2013, 8, e60796. [CrossRef] [PubMed]

43. Narasimhulu, S. New cytochrome P450 mechanisms: Implications for understanding molecular basis for drug toxicity at the level of the cytochrome. Expert Opin. Drug Metab. Toxicol. 2010, 1-15. [CrossRef]

Sample Availability: Samples of the compounds 7-12 are available from the authors.

(C) 2018 by the authors. Licensee MDPI, Basel, Switzerland. This article is an open access article distributed under the terms and conditions of the Creative Commons Attribution (CC BY) license (http://creativecommons.org/licenses/by/4.0/). 